\title{
Female Students' Attitude towards Abortion
}

\author{
Kpolovie, Peter James and Oguwike, Amarachi \\ Psychology Department, Faculty of Education, University of Port Harcourt \\ *Corresponding Author:, Kpolovie, Peter James, Psychology Department, Faculty of Education, \\ University of Port Harcourt.
}

\begin{abstract}
This investigation adopted cross-sectional survey research design to ascertain the attitude of female undergraduates and secondary school students towards abortion. A random sample of 1,300 was drawn with Table of Random Numbers from the 5,353,534 population of female students in Nigeria for the study. Data collection instrument was Abortion Attitude Questionnaire that had 0.89 Cronbach's Alpha reliability and Exploratory Factor Analysis that revealed very high validity as all the 15 items loaded highly on one and the same factor loading that accounted for $77 \%$ of the variability in attitude towards abortion. Each of the six null hypotheses was rejected. Female students' education level, age, religious believe, marital status, and location significantly influenced their attitude towards abortion. Virtually all the respondents, 1186 (91.2\%), very strongly asserted that abortion should be legalized. Legalization of abortion in line with pro-abortion theories was recommended.
\end{abstract}

Keywords: Abortion; Attitude; Attitude towards abortion; Female students; Legalization of abortion; Education level; Age; Religious believe; Marital status; Location.

\section{INTRODUCTION}

Abortion is a global issue in our contemporary society. In developing countries, especially Nigeria, evidence of abortion is obvious in towns and villages as undeveloped neonates are discovered around bush paths, behind maternity premises and besides university hostels and public borrow-pits. Some pharmacy stores have been shut down and doctors apprehended for unlawful participation in practising abortion. Zastrow and Krist-Ashman (2007), defined abortion as the "termination of pregnancy by removing an embryo or fetus from the uterus before it can survive on its own outside the womb". This act is observed to be done by all classes of women, especially female undergraduates and secondary school students from all socio-economic and marital status; cultural and religious backgrounds are no restrictions. Early initiation of coitus in the adolescent is often done without birth control and many result in pregnancy which most likely lead to abortion (National Statistical Service, Ministry of Health, and ICF, 2017).

A close observation of the incidence of abortion in Nigeria shows that abortion is very rampant. It is a common practice among female undergraduates and secondary school students. Personal experiences by the researchers of frequent occurrence of complications from abortion which often result in death across the states and in various hospitals throughout the country confirm the high rate of abortion in Nigeria. The Nigeria Demographic and Health Survey affirmed the high rate of abortion when it revealed that 91.73 percent of government hospitals and 97.58 percent of private hospitals in Nigeria have attended to patients suffering from abortion complications on an annual basis (National Population Commission Federal Republic of Nigeria, 2014).

In Port Harcourt alone yesterday (October 28, 2017) a girl of 17-year old in one secondary school student died as a result of complications from abortion of a pregnancy of about three months old. Another case was an undergraduate student who aborted a pregnancy in a roadside chemist. Few hours, later she complained of pains in her lower abdomen and was rushed to University of Port Harcourt Teaching Hospital where she died of the complications. Cases of this nature are frequent occurrence in various parts of Nigeria.

Enquiries have shown that abortion is done for several reasons. The most common and obvious reason of all the considerations is that abortion as a last resort to unwanted pregnancy. For female 
undergraduates and secondary school students, a pregnancy is principally unwanted because of the fear and shame of interruption in education, fear of parents' rejection, and the stigma associated with bringing up a child born out of wedlock, as well as the fact that a pregnant female may be ignorant of the person responsible for the pregnancy.

Abortion is observed to be done at any stage of pregnancy. Most people carry it out at the first trimester, others at the second trimester and a few even at the last trimester notwithstanding the dangers that could result from such acts. A large number of female undergraduates and secondary school students who seek abortion, do so personally at home, taking self-prescribed drugs and herbs. Some carry out abortion personally by self-administration of drugs that they have seen from the social media online as the Revolutionary Information Age has made possible (Kpolovie \& Lale, 2017; Kpolovie \& Onoshagbegbe, 2017). Some get it done with drugs or herbs prescribed by unprofessional doctors, nurses, midwives pharmacist as well as traditional birth attendants/herbalists. However, a few get it done secretly in private hospitals and clinics by professional doctors and nurses. Abortion, though widely practised in the Nigerian society, has long-term attendant consequences that include physical health problem, psychological and social problems that are dangerous and destructive, sometimes culminating in death.

As a worldwide issue, abortion has been a serious concern of the government of every nation, religious group, and some non-governmental organizations. Although several developed nations like the United States of America and the United Kingdom have legalized abortion (Alamieyeseigha \& Kpolovie, 2013), yet many countries such as Nigeria has not legalized it and so it is prohibited and regarded as a criminal/illegal offence except for remarkably few life-saving situations where the life of a pregnant woman is in danger.

In countries where abortion is considered a criminal act, a lot of anti-abortion campaigns are regularly carried out to enlighten the public, mainly the female folk on the dangers and consequences of abortion as a way to discourage its practice. Various international bodies, women health advocates, government and non-governmental bodies, including religious groups engage seriously in fight against abortion in Nigeria. These campaigns are done via seminars, health talks/programs, school clubs and jingles in radio and television, publications in newspapers and magazines, as well as national and international conferences among others. Despite these anti-abortion campaigns, the researchers have observed that abortion is still very rampant in the country, particularly among female undergraduates and secondary school students. Anastasi and Urbina (1997:418) defined attitude as a "tendency to react favourably or unfavourably towards a designated class of stimuli, such as national or ethnic group, a custom or an institution." This means that attitude is a positive or negative inclination towards a specific thing, group of persons or a practice as posited by Kpolovie, Joe and Okoto (2014) and Kpolovie and Awusaku (2016). This implies that attitude is a feeling that propels and is expressed in an action.

In a similar vein, Hawkins, Best and Coney (2001:399) defined attitude as "learned predisposition to respond in a consistently favourable or unfavourable manner with respect to a given object". This means that the attitude is not only an effective tendency, but it is also behavioural, both of which are influenced by one's perception or beliefs. Attitude therefore as seen by the current researchers is a typical behavioural pattern or response to stimuli or social object that is influenced by one's feelings, beliefs, and sense of judgment. This implies that people's attitudes are evident in their response to something, just as attitude of female undergraduates and secondary school students towards abortion is examined in this study. In this study, a female's attitude is considered positive if she favours /accepts or encourages abortion, and is considered negative if a female disapprovals or discourages abortion.

Abortion is an important topic of discussion, particularly in regards to reproductive health and family productivity. According to Shiers(1999), abortion is "the termination of pregnancy before 24weeks of gestation". In other words, abortion is the act of bringing a pregnancy to an end before the sixth month. The World Health Organization $(2004 ; 1998)$ defined abortion as "the termination of pregnancy before the embryo/fetus attains the age of viability". In defining the age of viability, Okoye(2006) explained that in Nigeria and many other countries, the age of viability is accepted to be 28 weeks of gestation, which is the $7^{\text {th }}$ month of pregnancy. This connotes any removal of fetus from the uterus at the $7^{\text {th }}$ month of pregnancy or after that can be considered as birth rather than abortion. In consonance with 
the view of Ramalingan (2006) abortion is the "premature termination of pregnancy, and from the seventh month, a fetus could be considered as matured.

Furthermore, Agbakwuru and Ekechukwu (2009:91), assert that abortion is "the deliberate expulsion of an embryo or fetus."Abortion as in this view is a willful and intentional act of interfering with a pregnancy, not attaching importance to the stage at which the pregnancy is terminated. Also, it implies that some abortions are induced, some are not. In line with this view, Okoye(2006) outlined three classes of abortion based on the circumstances that led to it. These include; spontaneous abortion, which is natural, therapeutic abortion which is life-saving and induced abortion which he called 'criminal or illegal' abortion. Okoye also explained that induced abortion is an "artificial or intentional termination of pregnancy using any of the numerous methods against the law of the country". Based on the above classification, the definition of abortion given by Agbakwuru and Ekechukwu (2009:91), falls within induced abortion. The researchers also consider abortion as the removal or evacuation of the embryo/fetus from the uterus before the seventh month of pregnancy.

Abortion has been the concern of many researchers over the years. A study carried out on abortion concerning common rights discovered that the limitation of human rights increases the case and exacerbates the problems and consequences of unsafe abortion (Ganatra, 2006; Alamieyeseigha \& Kpolovie, 2013). Further investigation on the dangers and consequences of abortion on women found that abortion is dangerous to health of women generally and particularly their reproductive health, concluding that abortion has both immediate and long-term consequences on women and society at large (Fisher, 2008).

Abortion is a crucial and sensitive topic with controversial inclinations, especially among Nigerian female undergraduates and secondary school students. Abortion is also a subject on which many people feel strongly in both directions; some favour it while others object to it. Emotions of people, particularly those of women run so high when issues on abortion are being raised or discussed.

Abortion is commonly practised by several women and girls in the various states in Nigeria. Those engaged in abortion do so even when they are aware that abortion is a dangerous procedure and against the law in the country. There are instances of severe pains and bleeding, infections, future miscarriages, complications in pregnancy and barrenness among other problems arising from abortion done unprofessionally that may result to death most times.

Psychological and emotional problems such as depression, guilt trauma, not forgiving oneself and transfer of aggression are also observed to be common experience of those who carryout abortion. Also, these emotional problems may result in some maladjusted behaviour and social problems that affect the home and society at large. Therefore, the problem of this study is determination of the attitude of female undergraduates and secondary school students towards abortion in Nigeria.

It is the purpose of this study to find out whether female undergraduate and secondary school students have positive or negative attitude towards abortion. Precisely, this investigation is aimed at ascertaining the attitude of female:

1. Undergraduates towards abortion in Nigeria.

2. Secondary school students towards abortion in Nigeria.

3. Whether abortion should be legalized in Nigeria.

Specifically, this investigation has provided answers to the following six research questions.

1. To what extent does the attitude of female undergraduate and secondary school students towards abortion differ in Nigeria?

2. What is the extent to which female students' attitude towards abortion differ with respect to age (11-20, 21-30, 31-40)?

3. What is the attitude of Christian and Muslim female students (both at tertiary and secondary school levels) towards abortion?

4. What is the attitude of married and unmarried female undergraduates and secondary school students towards abortion?

5. What is the attitude of urban and rural students towards abortion in Nigeria?

International Journal of Humanities Social Sciences and Education (IJHSSE)

Page $\mid 100$ 
6. What is the proportion of female students who very strongly assert that abortion should be legalized and those who very strongly affirm that abortion should not be legalized in Nigeria?

Six corresponding null hypotheses, statistically tested at 0.05 level of significance, guided this research as outlined:

1. There is no significant difference between the attitude of female undergraduate and secondary school students towards abortion in Nigeria.

2. Female students' attitude towards abortion does not significantly differ with respect to age (11-20, 21-30, 31-40).

3. There is no significant difference between Christian and Muslim female students' attitude towards abortion.

4. There is no significant difference between married and unmarried female students' attitude towards abortion.

5. Urban and rural students do not significantly differ in their attitude towards abortion.

6. There is no significant difference in the proportion of female students who very strongly assert that abortion should be legalized and those who very strongly affirm that abortion should not be legalized in Nigeria.

\section{CONCEPTUAL AND Theoretical RevieW}

\subsection{Attitude}

Existing conceptual, theoretical and empirical literature on the issue under investigation is briefly reviewed herein to correctly expose the knowledge gap that this study was executed to fill. Attitude makes up a large part of our daily thoughts and behavioural process; and is regarded as learned tendencies to positively and negatively evaluate some social objects, issues, persons, or particular ways of doing the concerned things. Hawkins, Best and Coney (2001: 394) defined attitude as "an enduring organization of motivational, emotional, perceptional, and cognitive process with respect to some aspect of our environment". In consonance, Eagly and Chaiken (1993), defined attitude as a stable set of mental views and assessments about some idea, object, or persons.

The above definitions of attitude expose the attributes and nature of attitude that is the dependent variable of the current investigation. First attitude is formed or learned, implying that it can be changed or unlearned. According to Wortman, Loftus and Marshall (1985), and Zimbardo and Leippe (1991), attitude is learned and developed through one's personal experiences or by observing the experiences of others. Attitude is relatively stable, enduring and persists for relatively longtime, therefore could only be changed with concerted efforts. Attitude motivates people to act in certain ways or help to shape and direct individuals' behaviour, inferring that attitude serves as guide to future behaviour. Kotler (2003), on this ground, acknowledged that people's behaviour could be changed by changing their attitude. On the other hand, Wortman, Loftus and Marshall (1985), stressed that attitude can no longer be considered as strong predictors of behaviours as they were originally, since it has been observed that people do not always behave in accordance with their attitudes. It can, therefore, be deduced that attitudeis only a predisposition to behave in certain ways but not a guarantee; meaning thata person's behaviour can contradict his or her attitude.

However, the extent to which attitude influences behaviour is conditional. In affirming this, Hockenbury and Hockenbury (2003), asserted that the correlation between attitude and behaviour is increased where the attitude is specific and accessible. They explained that accessibility refers to the strength of intensity of an attitude. The strength of an attitude means how quickly that attitude comes to the mind of the individual in response to a given social object. Hockenbury and Hockenbury (2003) further asserted that people's attitude tends to be in concordance with their behaviour when they feel very strongly about the social object, have personal experience of it and are interested in seeking out and participating actively in the social object. Furthermore, people's attitude influences their behaviour also when they anticipate a positive outcome in the particular circumstance of the social object that is eliciting the attitude. 
Social psychologists and psychometricians have identified three components of attitude. These include the cognitive, affective and behavioural components regarding factorial measurement via factor analysis (Kpolovie, 2017; 2011; Kpolovie, Joe \&Okoto, 2014; Kpolovie \& Awusaku, 2016). The cognitive component of attitude consists of a person's belief, thought, conclusions and perceptions about the given social object (Hockenbury \& Hockenbury, 2003). According to Wanken, Bohner, and Jurkowitsch (1997), these beliefs that make up the cognitive component of attitude need not be true before they are accepted as belief, but they only rued to exist, adding that positive beliefs lead to favourable attitude and negative beliefs culminate in unfavourable attitude towards the social object. On the other hand, the affective component refers to feelings and emotional reactions towards the attitude object. It is therefore in the affective component that the evaluative aspect of cognitive information or belief is expressed. Eagly and Chaiken (1993) acknowledge that the behavioural component of attitude comprises the predispositions to act or respond in certain ways towards the attitude object. In other words, this is the action component which exhibits the overall attitude. Debholkar (1994), noted that all the three components of attitude tend to be consistent and complementary; explaining that a change in one attitude component tends to produce related change in the other two components. Also that most attitudes have all the three components, though often attitudes tend to be more strongly rooted in either the cognitive or affective component.

Furthermore, attitude is mainly evaluative (Kpolovie, 2014). In essence, attitude has to do with an individual's sense of judgment and evaluation of something, idea or person, and this evaluation could be favourably positive or unfavourably negative (Wortman et al. 1985 and Hawkins et al. 2001). Also, Hockenbury and Hockenbury (2003) argued that attitude varies in intensity although all attitudes take a stance which could be purely positive or negative and sometimes ambivalent. Attitude is also expressed towards something, object, person or a situation which Wortman et al. (1985) referred to as the attitude object. Hawkin et al. (2001) affirm this in their definition of attitude as learned predispositions to respond in a consistently favourable or unfavourable manner with respect to a given object. Attitude can be summarized to mean the way an individual feels, sees, thinks and acts towards something in our environment.

It is believed that attitude influences behaviour, consequently, it is expected that people's behaviour should be consistent and in consonance with their attitudes. Nevertheless, this is not always the case. There are observed situations of discrepancies between one's attitude and behaviour. This emphasizes the fact that attitude is less stable predisposition to act in a particular manner (Hawkin et al. 2006). It is against this background that some theories of attitude have been postulated. Wortman and Loftus (1985), explained that persuasive communication, cognitive dissonance, and Daryl Bein's selfperception theories are some theories of attitude. However, the current study shall be based mainly on the Cognitive Dissonance theory of attitude. The researchers consider this theory more appropriate because of the emphasis the theory places on the fact that people are conscious of when their actions contradict their attitudes. And that such conflict causes inner discomforts which propels a desire for a change in action to be consistent with attitude, which is related to the research questions and assumptions of this investigation. 'Frequently seeking socio-psychological body equilibrium is largely part of what makes man a rational being' (Kpolovie, 2003; 2016a; 2003; 2017; 2016).

The cognitive dissonance theory was proposed by Leon Festinger in 1957. This theory is primarily considered regarding the discrepancies between attitude and behaviour. According to Festinger as cited by Gleitman et al. (2004), such discrepancies result in a state of distress in an individual. Wood (2000) explained that cognitive dissonance is a disconcerting emotional state that occurs when two beliefs that a person hold are inconsistent with each other, or when there is disagreement between one's attitude and behaviour. Affirmatively, Akinde (2005), stated that cognitive dissonance is the unpleasant psychological tension we experience when we notice or find out inconsistency or gaps simultaneously between two attitudes or our attitude and behaviour.

Gleitman et al. (2004) and Debholkar (1994) expounded that cognitive dissonance theory is based on three fundamental assumptions. Firstly, human beings are sensitive to inconsistencies between their actions and beliefs. This implies that, at every point in time, we realize to a certain extent when our actions are inconsistent with our attitudes. Secondly, the theory assumes that recognition of this inconsistency will cause a dissonance which will motivate dissention. On this note, Dabholkar (1994), stressed that the degree of the dissonance varies with the importance of attitude (belief) as well as the 
degree of consistency between one's behaviour and this belief/attitude. Finally, the third assumption is that dissonance will be resolved basically by changing one's beliefs, action or perception of action.

\subsection{Abortion}

Life begins at conception since all the inherited features of an individual are already set at conception (O'Rahilly \& Muller, 2010; 2001). Nevertheless, the destruction of life at conception which is known as 'abortion' is a popular practice by women all over the world. According to the World Health Organization (1998), abortion is defined as the termination of pregnancy before the embryo/fetus attain the age of viability. Okoye(2006), explained that the age of viability of an embryo or fetus in many countries including Nigeria is accepted to be 28 weeks of gestation, which is the $7^{\text {th }}$ month of a pregnancy. In consonance, Ramalinga, (2006) viewed abortion as the premature termination of pregnancy. Abortion is also considered as a deliberate and willful act of expelling an embryo or fetus from the uterus by artificial means and so prohibiting the development of an embryo/fetus (Agbakwuru, and Ekechukwu, 2009).Put differently, abortion is the method employed in preventing the birth of unwanted child by destroying the embryo/fetus.

A critical examination of the definitions in the preceding paragraph reveals that abortion is induced. Okoye (2006), affirms that induced abortion is the most common of the three types of abortion which include Induced abortion, spontaneous abortion, and therapeutic abortion. Okoye explained that therapeutic abortion is the abortion performed to save the life of a woman either from complication of pregnancy or other illness. Spontaneous abortion which is also known 'miscarriage' is an abortion that occurs naturally on its accord. Induced abortion is an artificial and intentional termination of a pregnancy against the law in Nigeria, using different methods.

However, Adeleke (2007), classified abortion into two major types spontaneous and induced abortion. According to Adeleke, there are two types of induced abortion which are therapeutic and criminal. In his view criminal abortion is an abortion performed illegally against the law. It is what Adeleke called criminal abortion that Okoye (2006) referred to as induced abortion and Reardon (2008), considered as elective abortion which is the interest of this study.

Several methods have been employed to induce abortion. Induced abortion could be done by procuring and drinking self-prescribed abortion drugs, traditional herbal preparations, concoctions, including mechanical manipulations with sharp/solid objects which are collectively considered as crude, unscientific, and native traditional methods. According to Bob (2002), the native and traditional method of abortion involves the drinking of deadly substances and mixtures such as potash, lime, Lipton, Nescafe, native herbs, gin and other chemicals as well as inserting herbs into their uterus which are all dangerous to the health of the fetus/embryo and of the pregnant person; as the chemicals often result in the death of both of them.

Some medical and surgical method as identified by Somiari(2000),Winikoff(2007), Okoye(2006) and Welch(2010), include dilation and curettage (D\&C), manual/electric vacuum aspiration, suction termination of pregnancy (STOP), vacuum curettage, in addition to distillation and evacuation (D\&E).Other advanced methods include hysterectomy, mifepristone, misoprostol, abortion pills and dilation and extraction.

Henshaw, Singh, Oye-Adenirin, and Shelton (1998), in their investigation of the methods employed by abortion seekers and providers in Nigeria using a random sample of 3,962 women hospitalized for abortion complication in 602 private and 139 public hospitals, found that dilation and curettage and vacuum aspirations are the most commonly used method among the methods earlier identified. However, Okoye (2006) clarified that, the stage of the pregnancy determines the method employed.

Okoye (2006), submitted that abortion is carried out at different stages of a pregnancy which could be the first trimester, which is considered early abortion, while the second and third trimester is considered late abortion. In the same vein, Berer (2002), observed that majority of women have abortion before 12 weeks of gestation being the first trimester, and few others seek abortion from 1628 weeks of gestation, that is, within the second and third trimesters. According to Berer, the second and third-trimester abortion requires excellent skills which most providers do not have, thereby increasing the risk and complications of abortion. Alan Guttmacher Institute (2007)found that threequarter of a million Nigerian women have induced illegal abortion each year out of which $87 \%$ do so before the firsteight weeks of gestation. Given the reasons for second and third trimester abortion in 
England and Wales, Ingham, Lee, Stone (2008) outlined that intervals in suspecting pregnancy due to irregular period and continued periods or dependence on contraception, delay in taking pregnancy test, and delay in deciding to have an abortion are some factors that contribute to the delay in having abortion by most women. Other reasons or factors for delay procurement of abortion were delays in first requesting for abortion after decision to have one, and as well as the delay in obtaining it after the first request and visit to the provider.

Theories of abortion are concerned with the different conceptions, views and schools of thought about abortion. Some of these theories are pro-abortion while others are anti-abortion. Irving (2000), classified abortion theories into two groups namely, the natural law theories and the ethical law theories. Among the natural laws are pro-choice, pro-life, liberals and conservatives. As explained by Irving, ethical law theories are theories that establish the fundamental principles(s) by which actions are judged morally right or wrong that include the theory of Hedonism, theory of Egoism, theory of Altruism, pragmatism theory and situation ethics theory. The Situation ethics theory holds that nothing is good or bad, right or wrong, but that the situation makes it so. From this position, if a woman aborts for the fun of it without any serious social or health reasons, such actions are considered wrong. But if on the contrary, the pregnancy is posing danger of any sort and is aborted, the action is said to be right. Pragmatism is the theory that insists on workability of any principle in practice. Therefore any action that is unrealistic and impracticable is a bad and wrong action, while the reverse is a good and right action. Judging from this position, abortion is both practicable and impracticable depending on the view of the individual concerned. Altruism ethical theory posits that abortion ought to be an act for the good of all concerned. Abortion from this view point is both right and wrong depending on the standpoint of which it is considered. It is a right action when it is done to save the life of the woman or for the reasons of fetal abnormalities. But it is wrong when abortion is done because a woman has unwanted pregnancy (Fisher, 2008).

While the Egoism theory holds that one ought to act to secure the greatest possible good for oneself; Hedonism theory holds that actions are right and good only if they produce pleasure and happiness and are wrong or bad if they produce pain and unhappiness. Both theories try to explain the driving force why anybody would do certain thing at a point in time. Thus, the driving force that would make a woman abort a pregnancy is that, she would consider her interest first before that of the fetus. Based on the rules of these two theories, it can be deduced that abortion is right and should be legalized because of the fetus which has limited right is independent of the mother whose interest must be first protected (Irving, 2000).

The Liberal theory holds that abortion should be permitted basically on demand, especially in cases where the woman is at risk, including cases of incest or rape. This implies that, liberalist are proabortion and advocates for the legalization of abortion. In contrast, the Conservative theory argues that abortion can never be rationalized or permitted, as it is fundamentally immoral to kill an unborn child who is an innocent human being, no matter the circumstances or law, regardless of the woman's health, life, incest or rape. It can, therefore, be observed that the conservatives are anti-abortion (Yakubu, 2002).

Welch (2010) asserted that the pro-choice like the liberal are pro-abortion and are from the standpoint that the woman has the right to do whatsoever she wants with her body and a fetus in her uterus. Therefore, a woman has the right and freedom to terminate her pregnancy even when she wants it, and especially when her life is at stake. Thus, abortion is a matter of the woman's choice and decision. The 2009 Abortion Surveillance in United States by Pazol, Creanga, Zane, Burley and Jamieson (2012) on whether abortion saves life showed that the pro-choice advocates argued that without easy access to abortion, substantial number of women would die through complications and health problem from pregnancy. Lidesmoth et al. (1977) submitted that the pro-choice advocates consider it absurd to talk about the sanctity of the life of an unborn child which is not considered a full fledge autonomous human individual. The safety, well-being and welfare of the woman are paramount and should be sort for rather than that of the unborn child. Welch (2010) equally admitted that the pro-choice advocates rightly contend that every woman should have the same and equal access to abortion, in case they need to or desired to terminate a pregnancy. Furthermore, pro-choice maintains that no abortion law should violate a woman's constitutional right to privacy, and jeopardize her right and choice to manage her reproductive health. 
Conversely, Pro-Life Theories of abortion are very conservative by strongly asserting that life begins at conception and sees the fetus as complete human being and therefore has the right to life. The prolife advocates describe every abortion action as a criminal act of murder and mortal sin and strongly argue that in no condition should abortion be legalized (Yakubu, 2002). Emphasizing the standpoint against abortion, Irving (2000), noted that the Pro-life theorists uphold that abortion is not a good thing, and as such, no one should have abortion under any circumstances, including cases of rape and incest. According to Reardon, Makima and Sobie (2000), abortion only adds to and accentuates the traumatic feeling associated with sexual assault. Morkon (2009) studied American women and found that more than $85 \%$ of rape victims chose against abortion. In Nigeria, the findings from study of Alan Guttmacher Institute (2009), reported that $1 \%$ and $0.5 \%$ of rape and incest victims respectively account for the total number of reported abortion performed annually. Similarly, Welch (2010) maintained that the pro-life advocates argued that most abortions are for matters of convenience, and not because of rape, incest, or mother's life is endangered. The pro-life advocates also consider abortion for fetal abnormalities as a form of discrimination against disabled people which they condemn (Chuck, 2007). In this regard, Yakubu (2002) rightly posited that the Nigerian laws on abortion are based on the pro-life views of abortion, except for the few exceptions which are normal and usual with every rule as provided by the law.

The current researchers are interested in both the pro-abortion and anti-abortion theories. This study is therefore based on the two broad categories of abortion theories as they have overt and covert bearing with the Nigerian law. Basing the current research on both the pro-abortion and anti-abortion theories is indispensable to avoid bias and unfairness on the part of the researchers.

\title{
2.3. Empirical Review
}

The practice of abortion is a global phenomenon that is even approved and legalized in some countries. However, abortion is considered as anillegal and a criminal act in Nigeria, except when the life of a woman is at risk. Yet, millions of women in Nigeria persistently resort to abortion regularly as an option for unwanted pregnancies. Henshaw, Singh, Oye-Adeniran, Adewale, Iwere and Cuca (1998) reported from their studies that annually, Nigerian women obtain approximately 610,000 abortions at a rate of 25 abortions per 1,000 women. This rate covers only the very few cases that the abortion was reported and done in the hospitals. Abortion cases in Nigeria that are not done in the hospitals (mainly government-owned hospitals) annually are more than fifty times of the few reported ones.That is, the abortion cases in Nigeria annually are not less than 30,500,000 (Kpolovie, Ewansiha \& Esara, 2017; Kpolovie, Oshodi \& Iwuchukwu, 2017; Kpolovie, 2012; National Population Census Federal Republic of Nigeria, 2014).

Abortion in Nigeria is governed by two different laws, the Criminal Code Act. CAP C38 Law of the Federation 2004, session 228, 229, 230 governs the southern part of the country which is largely Christian religiously. Clearly stated, the penalty for abortionin the referred Law reads thus:
228. Any person who with intent to procure miscarriage of a woman whether she is or not without child, unlawfully administer to her or cause her to take any or other any or other noxious thing, or uses any force or any kind, or uses any other means whatsoever, is guilty of a felony, and is liable to imprisonment for fourteen years.

\begin{abstract}
229. Any woman who with intent to procure her own miscarriage, whether she is or is not with a child, unlawfully administer to herself any poison or other noxious thing, or use any force of any kind, or uses any other means whatsoever, or permits any such thing or means to be administered or used to her, is guilty of a felony, and is liable to imprisonment for seven years.
\end{abstract}

230. Any person who unlawfully supplies to or procures for any person anything whatever, knowing that it is intended to be unlawfully used to secure the miscarriage of a woman, whether she is or is not with child is guilty of a felony, and is liable to imprisonment for three years.

While the Northern Nigeria which is predominantly Muslim states is governed by the Penal Code. CAPP3, Laws of the Federation 2004 in sessions 232, 233, and 234. These sessions read thus: 
232. Whoever voluntarily causes a woman with child to miscarry shall, if the miscarriage is not caused in good faith for the purpose of saving the life of the woman, be punished with imprisonment for a term which may extend to fourteen years or with fine or with both.

233. Whoever with intent to cause the miscarriage of a woman whether with child or not does an act which causes the death of that woman, shall be punished with imprisonment for a term which may extend to fourteen years and shall also be liable to fine; and if the act is done without the consent of the woman, with imprisonment for life or for any less term and also be liable to fine.

234. Whoever uses force on a woman and thereby unintentionally causes her to miscarry, shall be punished with imprisonment for a term which may extend to three years or with fine or with both; and if the offender knew that the woman is with child, he shall be punished with the imprisonment for a term which may extend to five years or with fine or with both.

It is then obvious that both the Criminal and Penal Codes provide a fourteen years jail term for an abortion provider. From a critical analysis of the two codes, it can, therefore, be deduced that both Christian and Islamic religions condemn the practice of abortion. Commenting in this regard, Yakubu (2002) remarked emphatically that abortion in Nigeria is regarded from all aspect as the killing of an unborn child which is criminal homicide or murder. On the same note, Okoye (2006) stressed that, abortion in Nigeria is considered an illegal and immoral act by law, religious bodies and even our cultural institutions.

Despite the prohibition of abortion by the law in Nigeria, except for the legal reason to save the life of a woman, millions of them still have numerous reasons for procuring abortion. Henshew Singh, OyeAdeniran, Adewale, Iwere and Cuca (1998), in their study on the magnitude of abortion in Nigeria, sampling 672 hospitals drawn from different part of the country found that, there are approximately 610,000 abortions carried out yearly, which represents a rate of 25 abortions per 1,000 women. In their comments, it was noted that this national rate of the incidence of induced abortion is higher than most Western European countries and is more than the1995 U.S. rate of about 23 abortions per 1,000 women where abortion is legalized. The same source in their first findings reported on the regional differences of induced abortion on the four regions of Nigeria, recorded an observed high rate of abortion in the southwest with approximately $46 \%$ abortion per 1,000 women, somewhat lower in the South-East and South-South regions and much lower with 10 and 13 abortion per 1,000 women, respectively.

This large number of women who chose to have abortion has their different reasons. Mundigo (2006) noted that generally and basically, all abortion seekers do so due to unwanted pregnancy. However, Mundigo identified social and economic factors as some specific reasons that females give for choosing abortion. Berer (2002) discovered empirically that some women, especially the teenage girls, perform abortion for the fact that they are unmarried and so want to avoid social stigma of being a single parent. Berer further discovered that most female students abort their pregnancy for reasons that they are in school and would not want to interrupt their education. The study of Alan Guttmacher Institute (2009) also identified more reasons for women's choice of abortion in Nigeria. The findings showed that female teenage students end their pregnancy for the fact that they are too young and so not matured enough to raise a child at the moment.

Personal observations by the current researchers show that criminal abortion carried out by female undergraduates and secondary school students were as a result of fear of parents, peer stigmatization/social stigma, and dropping out of school.

Abortion is often viewed by many, especially those who favour it as a solution to a problem, nevertheless, there are numerous attendant problems that result from abortion. Okoye (2006), noted that the complications and problem associated with abortion vary with the age of the pregnancy before the abortion, instrument used as well as the personnel (the abortion provider) involved in the procedure.

According to Okoye (2002), some of these problems occur immediately after or within few days/weeks of the abortion being a short-term implication, while others are long-term, occurring 
months or years later. Okoye further outlined pains, bleeding, splitting or tearing of the cervix, perforation of the uterus, infection and death as some of the immediate physical problems of procuring an abortion. Oye-Adeniran et al. (2004) reported the findings of their study that about 20,000 Nigerian women die as a result of abortion annually. Warriner (2006) also stated that globally about 68,000 women die each year due to abortion while 5.3million suffer temporary or permanent disability. Iniaghe (2007) reported that $50 \%$ of maternal death in Africa is attributed to abortion. Agbakwuru and Ekechukwu (2009) similarly identified that the physical problem emanating from abortion include the damage of cervical and uterine muscles which may later result in the perforation of the uterus, infections, haemorrhage, blood clotting disorder, inability to conceive and bear children in future (barrenness), and ectopic pregnancy. Other possible consequences of induced abortion include $17.5 \%$ chance of the future miscarriages, $24.3 \%$ chance of complications during future pregnancies, menstrual disorder, fever, insomnia, loss of appetite, weight loss, tiredness, vomiting, gastrointestinal disorders, frigidity and decreased work capacity (National Statistical Service, Ministry of Health, and ICF, 2017).

The psychological/emotional effect of abortion according to Okoye (2006), Olotu (2006) and Welch (2010) are induced prolonged depression, self-condemnation, anger, aggressiveness, regret, sadness, deep feeling of shame and hopelessness, acute grief and guilt, suicidal tendencies, low self-esteem, hatred/unforgiveness of self and partner, secret and torture and hunt of the irreparable past and thoughts of the "would be birth" of the aborted fetus. Furthermore, Shuping and Gacek (2010) in their examination of the consequences of abortion noted that the effect of the abortion is also obvious on the babies to be aborted when the abortion is not successful, and the fetus later develops. They observe that, such situation will result in the birth of physically, mentally, emotionally, psychologically deformed and abnormal babies.

Abortion providers are otherwise called 'abortionists'. Okoye (2006) explained that abortion providers are all who are involved in the business of carrying out or inducingabortion.Accordingto Okoye, many hands are involved in abortion and could be categorized into two as quacks and professionals. He further explained that the quacks are those without qualified training in medicine as medical doctor, which include mid-wives, nurses, medical students and the aborting women themselves as well as patent non-patent medicine dealers. While on the other hand, the professionals are experts in the medical field who are trained as qualified medical doctors and physicians.Berer (2002) also noted that the quacks do not possess the required skills, and as such, are associated with high risk of abortion complications.

Hord, Benson, Potts, and Billings (2006), Warriner and Shah (2006) and Alan Guttmacher Institute (2009), classified abortion providers into two, namely, physicians and non-physicians. The nonphysician refers to clinical procedures related to reproductive health and post-abortion services/care in the clinic or hospitals, and these include mid-wives, nurses, clinical officers and physician's assistants. Of the 610,000 abortions reported officially and handled in hospitals in Nigeria, Alen Guttmacher Institute (2009) stated that abortion by non-physicians are about 366,000 annually while only 244,000 abortions are performed by professionals or physicians annually. When the entire estimated 30,500,000 (made up of the officially reported 366,000 and the unreported 30,134,000 abortion cases in Nigeria annually) are used, approximately only 2,695,742 abortions are done by physicians yearly in Nigeria, while the overwhelming 27,804,258 abortions are conducted by nonphysicians on yearly basis in Nigeria (National Population Census Federal Republic of Nigeria, 2014; Kpolovie, Ewansiha \& Esara, 2017; Kpolovie, Oshodi \& Iwuchukwu, 2017; Kpolovie, 2012; World Health Organization, 2004).

Globally, married women in their late twenties or early thirties and above, with at least one child or none and more often several children typically engage in abortion annually (Ganatra, 2006). Married women very frequently turned to abortion as their last resort to unwanted pregnancy (Singh, 2006). Most female students abort their pregnancies for reasons that they are in school and would not want to interrupt their education as they would not want their education to be interrupted as a result of nursing their babies after delivery (Berer, 2002). A great majority of married female undergraduates approve even having multiple abortions in a year which indicates a positive attitude towards abortion.

In Nigeria, the empirical work carried out by Bankole, Oye-Aderan, Sing, Adewole, Wulf and Hussain, (2006) revealed that about a million married Nigerian women with and without a child have 
opted for and performed multiple abortions annually. This representsa very high rate of abortion incidence by married women in Nigeria where abortion is illegal.

Abortion is more prevalent among unmarried female students in Nigeria and in other developing countries. Even in the developed nations, incidence of abortion performed by unmarried females is relatively high in comparison with married females. According to Santrock as cited in Agbakwuru and Ekechukwu (2009), 19\% of abortions in the United States are executed by girls of 16 to 19 years old who are basically students. While less than $1 \%$ are done on those less than $15 y e a r s$. While Palma, Lince, and Raya (2006) reported that their study in Latin America showed a high rate of abortion, estimated at 36 abortions per 1,000 females aged between 15 and 19 years occur annually. A study in South and South-East Asia by Ganatra (2006)revealed that the percentage of unmarried female abortion seekers range between $1 \%$ to $15 \%$ which is a much smaller minority than the married ones as observed in some other regions of the world (National Statistical Service, Ministry of Health, and ICF, 2017).

Reardon (2008) and Agbakwuru and Ekechukwu (2009) observed that several unmarried females who seek abortion do so under high secrecy and confidentiality which make them to seek the service of quacks under no safe conditions, consequently resulting in a high risk of complications and even death most times. Palma et al (2006), Ganatra (2006), Fisher (2008), and Reardon (2008), explained that most unmarried female are coerced into abortion because of lack of emotional support from parents and partners (boyfriends), threat to withhold love by parents and partners, shame of not being married, shame of being stigmatized by classmates, including other social, financial, educational and health reasons. In a more recent study, Alan Guttmacher institute (2009) affirmed that the highest risk group of abortion seekers in Nigeria is the unmarried females.

Abortion is observed to be a common practice by both women of rural and urban residence (including teenagers). The geographical location a female finds herself is not a hindrance for her opinion to terminate unwanted or unintended pregnancy.

A survey in Mexico by Mundigo (2006)revealed that most rural females are much more exposedto crude methods of abortion than their counterparts in urban areas as those in the rural settings often use abortifacients from traditionalists and local chemists. In a similar study, Okoye (2006) and Alan Guttmacher Institute (2009) showed that most Nigerian rural women are at risk of unsafe abortion compared to their counterparts in the urban area who have access to safe abortion. Most rural female students because of fear, patronise quack abortion providers such as medicine vendors, traditional providers (herbalist), and patent medicine dealers. These methods according to Mundigo (2006), are hazardous as they subject the individuals to dangerous procedures such as inserting wires or roots/herbs into the uterus, taking excess dose of quinine and other drug substances. However,the World Health Organization (2004) and Ganatra (2006) noticed that the medical/surgical methods of abortion which most urban women employed are fast spreading to the rural women as technology becomes more widely accessible. In a similar view, Ramachander and Pelto (2005), also reported that the knowledge and awareness of rural students concerning medical/surgical methods which are considered safe cannot be underestimated as most rural females seek such providers like their urban counterparts. Inaghe (2007), nevertheless observed that no abortion is safe, even if the pregnancy is successfully terminated without any obvious complication, as the psychological scars left by abortion on a woman never heal, no matter how desperate a woman may be.

\title{
3. Methodology
}

Survey research method was employed in execution of this investigation. Kpolovie (2016: 250) and Kpolovie (2010: 376) asserted that:

\begin{abstract}
Survey research refers to any developmental field investigation that systematically collects, analyzes and synthesizes quantitative data on a large representative sample of a given population to cross-sectionally or longitudinally identify, describe and explain the relative incidence, distribution and interrelations of political, educational, psychological, sociological, commercial or economic and clinical variables, as well as other characteristics about the sample through data obtained from personal interview, telephone interview, self-administered inquiry and computer-assisted inquiry for accurate generalization to cover the entire population.
\end{abstract}


This definition which satisfactorily covers survey research in its entirety is composed of eight small distinct and very important units or elements that characterize survey as follows.

(1) Survey research involves developmental study that not only reveals or unveils the current or prevailing state of affairs, but also discovers changes that occur in certain features, characteristics and variables about a specific population by closely examining the nature, direction and rate of the changes, the how, which, what, who, where, when and partial why of the changes over a period of time.

(2) Survey research demands field study by collecting data from the real world through active interaction of the investigator with the subjects via standardized interviews. Survey does not subject the subjects to the artificiality of strictly controlled environments for the purpose of data collection. It studies the participants in almost naturalistic setting.

(3) Survey research requires collection of a wide variety and large volume of data that are quantitative (not qualitative) or that are quantifiable and analyzes them with different types of complex statistics for arriving at dependable answers to the research questions and testing of the tenability of the postulated hypotheses. With the research questions answered and hypotheses tested, appropriate and clear interpretations are given to adequately meet the purpose of the study.

(4) Large representative sample of the specific population under investigation must be randomly drawn and studied in great detail for appropriate and accurate inference or generalization to be made about the population from the sample data. It is when the sample is not only large, but also randomly derived to most proportionally represent the population, that right inference can on the basis of suitable statistics, be made from the sample to cover the population.

(5) Cross-sectional and longitudinal are the two main designs, one of which every serious survey research must adopt. Cross-sectional survey research design developmentally studies characteristics of randomly sampled subjects of different ages, classes or levels from different independent groups contemporaneously or simultaneously and compares the difference or changes across the various ages, classes or levels. Longitudinal survey research design studies developmental change and constancy in specific attributes of the same sample of participants or subjects repeatedly over an extended span of time for comparison to be made across the different ages and periods of time. Closely related to cross-sectional and longitudinal survey designs are successive independent samples design and trace survey design.

(6) Survey research is used mainly for purpose of identification, description, explanation and prediction of states of affairs about certain phenomena and variables, and their interrelations in a natural setting over time and different age-related groups. Recall from the explanation in Chapter 1 , that generally, research is used for description, explanation, prediction and control of phenomena.

(7) The spheres of life that survey research could be applied or adopted include:

a. Politics as in opinion polls for determination of a preferred presidential aspirant or candidate.

b. Psychology as in the investigation of human development or in studying characteristics of individuals of different birth-order across different ages over time.

c. Clinical in the study of HIV patients; attitude towards and interest in counselling on positive safety practices.

d. Economic or commercial in the investigation of demand and supply of various commodities in the market.

e. Sociology in the study of cultural practices or social organizations.

f. Education as in the investigation of students cognitive and physical changes over time; or in studying teachers' job satisfaction across ages and years or service over time throughout the federation.

(8) The sources for or techniques of collecting data in survey research are personal interview (inhome, executive, mall-intercept and purchase-intercept interview); telephone interview (like phone and television assisted interviews); self-administered inquiry (via questionnaire 
administration, mail, drop-off and mail-panel interviews); and computer-assisted interview (fax, E-mail and internet).

It is clear from the above definition alone that survey research is a specific method of investigation that demands great carefulness, attention, commitment and seriousness, as well as rigorous and extensive interviews and statistical analyses on the part of the researcher.

The research design adopted for this investigation is cross-sectional survey design. "Cross-sectional survey research design developmentally studies characteristics of randomly sampled subjects of different ages, classes or levels from different independent groups contemporaneously or simultaneously and compares the difference or changes across the various ages, classes or levels" (Kpolovie, 2016: 251). The cross-sectional survey is a developmental field study that is characterised with a large representative sample of subjects drawn randomly from different age levels to be comparatively investigated simultaneously. Cross-sectional survey research design could be used for investigation of physical counts, attitudes, opinion, feelings and thoughts of the entire population on any given phenomenon (Kpolovie, 2010; 2016). The researchers collected data from a large sample of female undergraduates and secondary school students across the 36 States in Nigeria so as to determine their attitude towards abortion as at the time of the investigation.

\subsection{Population and Sample of the Study}

Nigeria has a total population of 191,197,655 of which 13,383,836 are students in universities and secondary schools, irrespective of the ownership of the educational institution (World Population Review, 2017). The 13,383,836 students constitute $7 \%$ of the population of Nigeria in 2017 . While male students are $8,030,302$ that is equivalent to $60 \%$ of the student population and $4.20 \%$ of the total national population; $5,353,534$ that is $30 \%$ of the student population and $2.80 \%$ of the total federal population are female students. Of the $\mathbf{5 , 3 5 3 , 5 3 4}$ female students that constitute the functional population of this investigation, $3,747,474$ that is $70 \%$ of the entire female students are in secondary schools and 1,606,060 that is equivalent to $30 \%$ of the female students are in universities. A sample of 1,300 female students; composed of 855 female secondary schools and 445 female undergraduates; was randomly drawn with the aid of Table of Random Numbers for this investigation. The sample of 1,300 from the total 5,353,534 female students in Nigeria is indeed a large enough sample for a cross-sectional survey research in line with standard characteristics of a good sample representativeness, accuracy and precision (Kpolovie, 2017; Krejcie \& Morgan, 1970; Kpolovie, 2011).

\subsection{Instrument for Data Collection}

A 7-point Likert-type questionnaire involving Very Strongly Agree (VSA), Strongly Agree (SA), Agree (A), Undecided (UD), Disagree (D), Strongly Disagree (SD), and Very Strongly Disagree (VSD) named Abortion Attitude Questionnaire (AAQ) was used in collecting data for the study. The instrument was developed by the researchers to elicit information from female undergraduates and secondary school students so as to assess their attitude towards abortion. The Abortion Attitude Questionnaire had 15 items with inter-item correlations that ranged between 0.33 to 0.57 and itemtotal correlations that ranged from 0.71 to 0.94 . The inter-item correlations and item-total correlations are undisputable evidence of suitable internal consistency reliability and construct validity of the AAQ instrument. As a further measure of internal consistency reliability of the Abortion Attitude Questionnaire, the validation data of the AAQ were subjected to Cronbach's Alpha analysis and a 0.89 reliability coefficient was got that indicates very high reliability (Kpolovie, 2017; 2016; 2014; $2011 ; 2010)$. The validation data were further subjected to Exploratory Factor Analysis that revealed very high validity of the AAQ as all the 15 items loaded highly on one and the same factor loading that accounted for $77 \%$ of the variability in attitude towards abortion. This indicates that the instrument has an excellent construct validity (Kpolovie, 2017; 2014; 2011).

The Abortion Attitude Questionnaire had an added section that was made up of one categorical item that sought to elicit information on whether or not abortion should be legalized. This item was to enable the investigators obtain data for answering the sixth research question on the proportion of 
female students who very strongly assert that abortion should be legalized and those who very strongly affirm that abortion should not be legalized in Nigeria.

Descriptive statistics was used to answer each of the research questions, and the most suitable statistical test was applied in testing each of the null hypotheses (Kpolovie, 2011a). Independent samples T-Test was adopted for testing the first, third, forth, and fifth null hypotheses. While Analysis of Variance (ANOVA) was employed in testing the second null hypothesis, Test of Proportion was used in testing the sixth null hypothesis. Each of the null hypotheses was tested at 0.05 level of significance. IBM SPSS ${ }^{\circledR}$ Statistics Version 23 was employed in execution of all the statistical analyses of this study.

\section{RESUlts PRESENTATION}

Table1: T-Test for Ho:1 - Abortion attitude of female Undergraduates and Secondary School students

[DataSet1] C:IUsers\KPOLOUIE\Documents\Abortion Attitude.sav

\begin{tabular}{|l|l|r|r|r|r|}
\hline \multicolumn{7}{|c|}{ Group Statistics } \\
\hline & Education level & $\mathrm{N}$ & \multicolumn{1}{c|}{ Mean } & Std. Deviation & Std. Error Mean \\
\hline Attitude towards abortion & Undergraduate & 445 & 83.3753 & 14.86124 & .70449 \\
\cline { 2 - 6 } & Secondary school & 855 & 51.2713 & 26.47342 & .90537 \\
\hline
\end{tabular}

\begin{tabular}{|c|c|c|c|c|c|c|c|}
\hline & \multicolumn{2}{|c|}{\begin{tabular}{|c|} 
Levene's Test for \\
Equality of Variances
\end{tabular}} & \multirow[b]{2}{*}{$\mathrm{t}$} & \multirow[b]{2}{*}{ df } & \multirow[b]{2}{*}{$\begin{array}{l}\text { Sig. (2- } \\
\text { tailed) }\end{array}$} & \multirow[b]{2}{*}{$\begin{array}{c}\text { Mean } \\
\text { Difference }\end{array}$} \\
\hline & & $\mathrm{F}$ & Sig. & & & & \\
\hline \multirow[t]{2}{*}{ Attitude towards abortion } & $\begin{array}{l}\text { Equal variances } \\
\text { assumed }\end{array}$ & 155.736 & .000 & 23.708 & 1298 & .000 & 32.10394 \\
\hline & $\begin{array}{l}\text { Equal variances not } \\
\text { assumed }\end{array}$ & & & 27.985 & 1290.946 & .000 & 32.10394 \\
\hline
\end{tabular}

The first part of Table 1 has shown the descriptive statistics that answers the first research question of this study. While the mean and standard deviation of the 445 undergraduates' attitude towards abortion are 83.3753 and 14.86124 , respectively; the 855 female secondary school students' attitude towards abortion has a mean of 51.2713 and a standard deviation of 26.47342. It can be discerned very vividly from the second part of Table 1 that the computed t-value for equal variances not assumed is $\mathbf{2 7 . 9 8 5}$ which is statistically significant at 0.001 alpha for a two-tailed test. Therefore, the first null hypothesis of no significant difference between undergraduates and secondary school students in their attitude towards abortion is rejected; [ $\mathrm{t}(1290.946)=27.985 ; \mathrm{p}<0.05$ ]. The undergraduates' attitude towards abortion is significantly better than those of the female secondary school students. This may be implying that experience, intellectual and physical maturation possibly influence students' attitude towards abortion as reflected in World Values Survey (2015).

Table2: Oneway ANOVA for Ho: 2 - Female students' attitude towards abortion by Age

\begin{tabular}{|c|c|c|c|c|c|c|c|c|}
\hline \multicolumn{9}{|c|}{ Descriptives } \\
\hline \multicolumn{9}{|c|}{ Attitude towards abortion } \\
\hline & \multirow[b]{2}{*}{$\mathrm{N}$} & \multirow[b]{2}{*}{ Mean } & \multirow{2}{*}{$\begin{array}{l}\text { Std. } \\
\text { Deviation }\end{array}$} & \multirow[b]{2}{*}{ Std. Error } & \multicolumn{2}{|c|}{$\begin{array}{l}\text { 95\% Confidence Interval for } \\
\text { Mean }\end{array}$} & \multirow[b]{2}{*}{ Minimum } & \multirow[b]{2}{*}{ Maximum } \\
\hline & & & & & Lower Bound & Upper Bound & & \\
\hline $11-20$ & 521 & 33.1996 & 11.27806 & .49410 & 32.2289 & 34.1703 & 15.00 & 53.00 \\
\hline $21-30$ & 464 & 70.5582 & 10.26563 & .47657 & 69.6217 & 71.4947 & 53.00 & 88.00 \\
\hline $31-40$ & 315 & 98.1048 & 4.59422 & .25885 & 97.5955 & 98.6141 & 88.00 & 105.00 \\
\hline Total & 1300 & 62.2608 & 27.72107 & .76884 & 60.7525 & 63.7691 & 15.00 & 105.00 \\
\hline
\end{tabular}

\begin{tabular}{|c|c|c|c|c|c|}
\hline \multicolumn{6}{|c|}{ ANOVA } \\
\hline \multicolumn{6}{|c|}{ Attitude towards abortion } \\
\hline & Sum of Squares & df & Mean Square & $\mathrm{F}$ & Sig. \\
\hline Between Groups & 876665.388 & 2 & 438332.694 & 4676.800 & .000 \\
\hline Within Groups & 121561.212 & 1297 & 93.725 & & \\
\hline Total & 998226.599 & 1299 & & & \\
\hline
\end{tabular}


Post Hoc Tests

\begin{tabular}{|c|c|c|c|c|c|c|}
\hline \multicolumn{7}{|c|}{ Multiple Comparisons } \\
\hline \multicolumn{7}{|c|}{ Dependent Variable: Attitude towards abortion } \\
\hline \multicolumn{7}{|c|}{ LSD } \\
\hline \multirow[b]{2}{*}{ (I) Age } & \multirow[b]{2}{*}{ (J) Age } & \multirow{2}{*}{$\begin{array}{c}\text { Mean Difference (I- } \\
\text { J) }\end{array}$} & \multirow[b]{2}{*}{ Std. Error } & \multirow[b]{2}{*}{ Sig. } & \multicolumn{2}{|c|}{$95 \%$ Confidence Interval } \\
\hline & & & & & Lower Bound & Upper Bound \\
\hline \multirow[t]{2}{*}{$11-20$} & $21-30$ & $-37.35857^{*}$ & .61797 & .000 & -38.5709 & -36.1462 \\
\hline & $31-40$ & $-64.90515^{*}$ & 69097 & .000 & -66.2607 & -63.5496 \\
\hline \multirow[t]{2}{*}{$21-30$} & $11-20$ & $37.35857^{*}$ & 61797 & .000 & 36.1462 & 38.5709 \\
\hline & $31-40$ & $-27.54657^{*}$ & .70678 & .000 & -28.9331 & -26.1600 \\
\hline \multirow[t]{2}{*}{$31-40$} & $11-20$ & $64.90515^{*}$ & 69097 & .000 & 63.5496 & 66.2607 \\
\hline & $21-30$ & $27.54657^{*}$ & .70678 & .000 & 26.1600 & 28.9331 \\
\hline
\end{tabular}

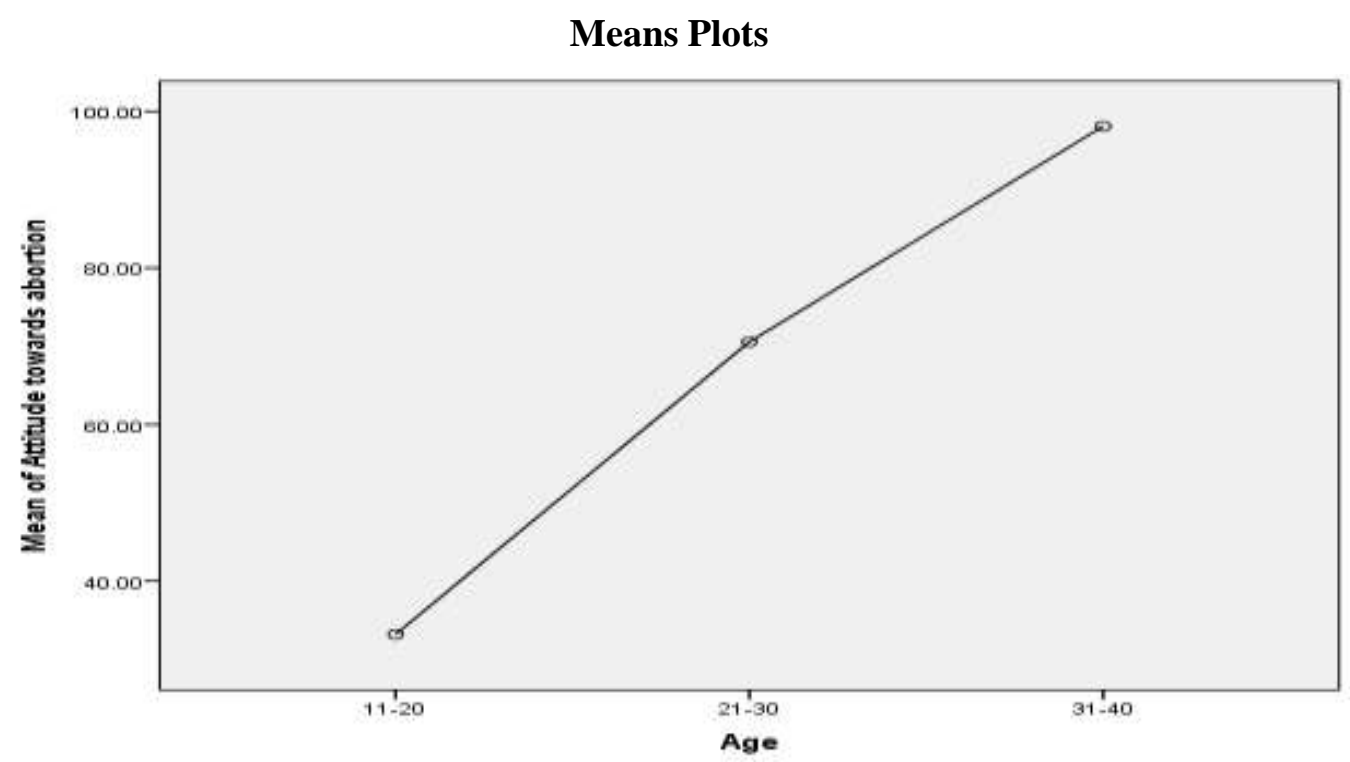

Answer to the second research question of this study is presented in the first part of Table 2 and further buttressed graphically with the last part, labelled Means Plot. The first and last part of Table 2 have revealed that that:

i) Female students aged 11-20 years, 521 in number, have a mean of 33.1996 and a standard deviation of 11.27806 in their attitude towards abortion.

ii) The 464 female students who are aged 21-30 years have a mean of 70.5582 and a standard deviation of 10.26563 in their attitude towards abortion.

iii) The attitude towards abortion of the 315 female students has a mean of 98.1048 and a standard deviation of 4.59422 .

iv) The grand mean and standard deviation of all the 1300 students' attitude towards abortion are 62.2608 and 27.72107 , respectively.

The second part of Table 2, labelled ANOVA, has shown the between groups sum of squares of 876665.388 , degrees of freedom of 2 , and a mean square of 438332.694 . The within groups sum of squares is 121561.212 with 1297 degrees of freedom and 93.725 mean square. While the total sum of squares is 998226.599 , the total degrees of freedom is 1299. The computed $\mathbf{F}$ is $\mathbf{4 6 7 6 . 8 0 0}$ that is statistically significant at 0.001 . Therefore, the null hypothesis of no significant age difference in students' attitude towards abortion is rejected; $[\mathrm{F}(2,1297)=4676.800, \mathrm{p}<.05]$.

The third part of Table 2, captioned Multiple Comparisons, has uncovered the specific pairwise comparisons that significantly differ statistically. Female students who are aged 11-20 years have significantly poorer attitude towards abortion than their counterparts who are aged 21-30 years; who in turn have significantly poorer attitude towards abortion than those aged 31-40 years. In other words, female students' attitude towards abortion differs significantly in line with their age. Female students within the age of 31 and 40 have overwhelmingly better attitude to abortion than those aged 
21 to 30 , who are also of significantly better abortion attitude than those aged between 11 and 20 years.

Table3: T-Test for Ho: 3 - Female students' attitude towards abortion by Religion

\begin{tabular}{|l|l|l|l|l|l|}
\hline \multicolumn{7}{|c|}{ Group Statistics } \\
\hline & Religion & $\mathrm{N}$ & Mean & Std. Deviation & Std. Error Mean \\
\hline Attitude towards abortion & Christian & 605 & 69.9124 & 24.93616 & 1.01380 \\
\cline { 2 - 7 } & Muslim & 695 & 55.6000 & 28.31474 & 1.07404 \\
\hline
\end{tabular}

\begin{tabular}{|c|c|c|c|c|c|c|}
\hline & \multicolumn{2}{|c|}{$\begin{array}{l}\text { Levene's Test for } \\
\text { Equality of Variances }\end{array}$} & \multirow[b]{2}{*}{$\mathrm{t}$} & \multirow[b]{2}{*}{ df } & \multirow[b]{2}{*}{ Sig. (2-tailed) } \\
\hline & & F & Sig. & & & \\
\hline \multirow[t]{2}{*}{ Attitude towards abortion } & $\begin{array}{l}\text { Equal variances } \\
\text { assumed }\end{array}$ & 18.516 & .000 & 9.606 & 1298 & .00 \\
\hline & $\begin{array}{l}\text { Equal variances } \\
\text { not assumed }\end{array}$ & & & 9.691 & 1297.822 & .00 \\
\hline
\end{tabular}

It can be seen in the first part of Table 3 that the 605 female students who are Christians have a mean of 69.9124 and a standard deviation of 24.93616 with regard to their attitude towards abortion. The attitude of the 695 Muslim female students towards abortion has a mean of 55.6000 and a standard deviation of 28.31474. The second part of Table 3 has shown a computed t-value of 9.691 (equal variances not assumed) and 1297.822 degrees of freedom. The computed $\mathbf{t}$ (9.691) is significant statistically at 0.001 alpha. Consequently, the third null hypothesis that "there is no significant difference between Christian and Muslim female students' attitude towards abortion" is rejected. Female Christian students have statistically better attitude towards abortion than their counterpart Muslim female students.

Table4: T-Test for Ho: 4 - Female students' attitude towards abortion by Marital Status

\begin{tabular}{|l|l|r|r|r|r|}
\hline \multicolumn{7}{|c|}{ Group Statistics } \\
\hline & Marital status & $\mathrm{N}$ & \multicolumn{1}{c|}{ Mean } & \multicolumn{1}{c|}{ Std. Deviation } & \multicolumn{1}{c|}{ Std. Error Mean } \\
\hline \multirow{2}{*}{ Attitude towards abortion } & Married & 682 & 59.8842 & 28.27108 & 1.08256 \\
\cline { 2 - 6 } & Unmarried & 618 & 64.8835 & 26.88084 & 1.08131 \\
\hline
\end{tabular}

\begin{tabular}{|c|c|c|c|c|c|c|c|}
\hline & \multicolumn{2}{|c|}{$\begin{array}{c}\text { Levene's Test } \\
\text { for Equality of } \\
\text { Variances }\end{array}$} & \multirow[b]{2}{*}{$\mathrm{t}$} & \multirow[b]{2}{*}{ df } & \multirow[b]{2}{*}{$\begin{array}{l}\text { Sig. }(2- \\
\text { tailed })\end{array}$} & \multirow[b]{2}{*}{$\begin{array}{c}\text { Mean } \\
\text { Difference }\end{array}$} \\
\hline & & $\mathrm{F}$ & Sig. & & & & \\
\hline \multirow[t]{2}{*}{$\begin{array}{l}\text { Attitude towards } \\
\text { abortion }\end{array}$} & $\begin{array}{l}\text { Equal variances } \\
\text { assumed }\end{array}$ & 1.722 & .190 & 8.529 & 1298 & .000 & 12.78223 \\
\hline & $\begin{array}{l}\text { Equal variances not } \\
\text { assumed }\end{array}$ & & & 8.522 & 1281.216 & .000 & 12.78223 \\
\hline
\end{tabular}

The Group Statistics in Table 4 has indicated that the 682 married students' attitude towards abortion has a mean of 59.8842 and a standard deviation of 28.27108; while the 618 unmarried students have a mean of 64.8835 and a standard deviation of 26.88084. The computed independent samples t-test is 8.529 (equal variance assumed) and a 1298 degrees of freedom. The calculated $\mathbf{t}$ (8.529) is statistically significant at 0.001 alpha for a two-tailed test. Therefore, the null hypothesis that "there is no significant difference between married and unmarried female students' towards abortion" is rejected; [t $(1298)=8.529, \mathrm{p}<.05]$. The unmarried female students are significantly better than the married female students in their attitude towards abortion.

Table5: T-Test for Ho: 5 - Female students' attitude towards abortion by Location

\begin{tabular}{|l|l|r|r|r|r|}
\hline \multicolumn{7}{|c|}{ Group Statistics } \\
\hline & Location & N & Mean & Std. Deviation & Std. Error Mean \\
\hline Attitude towards abortion & Urban & 725 & 59.2303 & 26.79265 & .99505 \\
\cline { 2 - 6 } & Rural & 575 & 66.0817 & 28.41496 & 1.18499 \\
\hline
\end{tabular}




\begin{tabular}{|c|c|c|c|c|c|c|c|c|}
\hline & \multicolumn{2}{|c|}{\begin{tabular}{|c|} 
Levene's Test \\
for Equality of \\
Variances \\
\end{tabular}} & \multirow[b]{2}{*}{$\mathrm{t}$} & \multirow[b]{2}{*}{$\mathrm{df}$} & \multirow[b]{2}{*}{$\begin{array}{l}\text { Sig. (2- } \\
\text { tailed) }\end{array}$} & \multirow[b]{2}{*}{$\begin{array}{c}\text { Mean } \\
\text { Difference }\end{array}$} & \multirow[b]{2}{*}{$\begin{array}{l}\text { Std. Error } \\
\text { Difference } \\
\end{array}$} \\
\hline & & $\mathrm{F}$ & Sig. & & & & & \\
\hline \multirow[t]{2}{*}{$\begin{array}{l}\text { Attitude towards } \\
\text { abortion }\end{array}$} & $\begin{array}{l}\text { Equal variances } \\
\text { assumed }\end{array}$ & 11.757 & .001 & -4.458 & 1298 & .000 & -6.85139 & 1.53690 \\
\hline & $\begin{array}{l}\text { Equal variances not } \\
\text { assumed }\end{array}$ & & & -4.428 & 1197.023 & .000 & -6.85139 & 1.54736 \\
\hline
\end{tabular}

The first part of Table 5 has shown the descriptive statistics that serves as the answer to the fifth research question of this investigation. While the mean and standard deviation of the 725 urban student' attitude towards abortion are 59.2303 and 26.79265, respectively; the 575 rural female students' attitude towards abortion has a mean of 66.0817 and a standard deviation of 28.41496. It can be discerned very vividly from the second part of Table 5 that the computed t-value for equal variances not assumed is $\mathbf{- 4 . 4 2 8}$ which is statistically significant at 0.001 alpha for a two-tailed test. The fifth null hypothesis that "urban and rural students do not significantly differ in their attitude towards abortion" is rejected; [t $(1197.023)=-4.428 ; \mathrm{p}<0.05]$. Surprisingly, the rural students' attitude towards abortion is significantly better than those of their urban counterparts. This might be because students in the rural areas have experienced the pangs of abortion illegally done either directly or vicariously than their counterparts in the urban areas as stated by Okoye (2006) and Yakubu (2002).

Table 6: Frequencies Analysis for Ho:6 - Percentage of female students who Very Strongly Affirm Legalization of Abortion

\begin{tabular}{|l|l|r|r|r|r|}
\hline \multicolumn{7}{|c|}{ Legalize Abortion } \\
\hline \multirow{2}{*}{ Valid } & Frequency & Percent & Valid Percent & Cumulative Percent \\
& Very Strongly Agree & 1186 & 89.2 & 91.2 & 91.2 \\
\cline { 2 - 6 } & Very Strongly Disagree & 114 & 8.6 & 8.8 & 100.0 \\
\cline { 2 - 6 } & Total & 1300 & 97.8 & 100.0 & \\
\hline Missing & System & 29 & 2.2 & & \\
\hline Total & 1329 & 100.0 & & \\
\hline
\end{tabular}

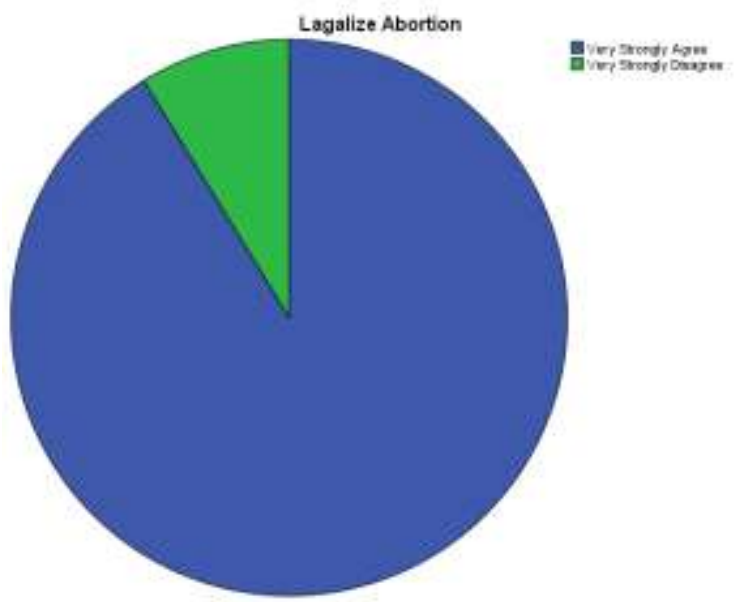

It can be discerned vividly from Table 6 that out of the 1300 female tertiary and secondary school students of this investigation, a significant overwhelming number, 1186, very strongly affirm that abortion should be legalized. Only a very few of the respondents, 114 precisely, hold that abortion should not be legalized. While the percentage of the respondents clamouring assertively for legalization of abortion in Nigeria is preponderantly as high as 91.2 , only extremely small percentage of 8.8 of female students that is against legalization of abortion in the country. The second part of Table 6, labelled Legalize Abortion has graphically expressed or illustrated the significant difference between the number of female students who assert very strongly that abortion should be legalized as shown in the portion of the graph that is coloured blue and their marginally small counterparts who posit that abortion should remain illegal in Nigeria as shown in the small section of the pie chart that is coloured green. The virtually unanimous call of the female students for legalization of abortion in Nigeria needs to be accorded due attention, and indeed granted; if decisions on the issue by the federal 
government are to be data-based. The need for data-based decisions cannot be overemphasised in Revolutionary Information Age that we live (Kpolovie \& Lale, 2017).

\section{CONCLUSION}

Categorically, all the five independent variables of this investigation have been found in the study to significantly influence female students' attitude to abortion. This accounts for why each of the null hypotheses was rejected. While undergraduates have significantly better attitude towards abortion than their counterparts in secondary schools; female students who are Christians significantly favour abortion than Muslim female students. Unmarried female students' attitude to abortion is statistically better than those of the married students. Similarly, rural female students have significantly better attitude towards abortion than urban female students. With regard to age, female students aged 31-40 are statistically better in their attitude towards abortion than those who are aged 21-30, and these, in turn, demonstrate profoundly better attitude to abortion than the female students within the age brackets of 11 and 20 years. Perhaps, the most dramatic and provocative finding of this investigation is that virtually all the female students $1186(91.2 \%)$ very strongly affirm that abortion should be legalized in Nigeria.

The virtually unanimous assertion of the female undergraduates and secondary school students that abortion should be legalized in Nigeria is very much in line with the egoism, hedonism, liberal, prochoice and pro-abortion theories of abortion. The Egoism theory posits that one ought to act so as to secure the greatest possible good for oneself. The Hedonism theory avers that actions are right and good only if they produce pleasure and happiness and are wrong or bad if they produce pain and unhappiness. It explains the driving force that would make a woman abort a pregnancy by considering her interest first before that of the fetus. The Liberal theory speculates that abortion should be permitted basically on demand, especially in cases where the woman is at risk, including cases of incest or rape. This implies that liberalists are pro-abortion and advocate the legalization of abortion.

The Pro-choice theory of abortion is liberal and is like the pro-abortion theory which maintains that a woman should have the right to do whatsoever she wants with her body and a fetus in her uterus. Therefore, a woman has the right and freedom to terminate whether her pregnancy should be allowed to develop to child delivery or not. Thus, abortion is a matter of the woman's choice and decision. The 2009 Abortion Surveillance in United States by Pazol, Creanga, Zane, Burley and Jamieson (2012) on whether abortion saves life showed that the pro-choice advocates argue that without easy access to abortion, substantial number of women would die through complications and health problems from pregnancy. In fact, like the pro-choice advocates, $91.2 \%$ of respondents of this study consider it absurd to talk about the sanctity of the life of an unborn child which is not considered a full fledge autonomous human individual. The safety, well-being and welfare of the woman are paramount and should be sort for rather than that of the unborn child. The female students under investigation strongly uphold that every woman should have the same and equal access to abortion, in case they need to or desire to terminate a pregnancy. Therefore no abortion law should violate a woman's constitutional right to privacy, and jeopardize her right and choice to manage her reproductive health.

The fervent assertion of female students that abortion be legalized is in line with the best practices in most developed world with a view to prevention or at least reduction of the high rate of female mortality due to abortion complications as a result of sharp practices, done mainly by quacks (OECD, 2017a; IMF, 2013; World Values Survey, 2015; ILO, 2014; OECD, 2017). If only abortion is legalized, those who have to do it can have access to get it done in public hospitals and renowned private medical centres as against the current practice that a person necessarily seeking abortion has to go to quacks who perform it unprofessionally in secrets that often culminate in complications and death (Gamatra, 2006).

Based on the findings, it is strongly recommended that the laws that forbade abortion in the country should be reviewed to legitimize abortion like what is obtainable in the developed world. In fact, even the natural tendency to try the forbidden may make some female students seek abortion.

Abstinence from sex is indeed the best way of preventing abortion. For married couples and singles who may not be able to practice strict abstinence, use of condom and the various existing family planning measures is highly recommended. 
The significance of this study is obviously inevitable and cannot be over emphasized. The findings of this study will be of useful value in helping the government, especially the federal and state Ministries of Health to embark on more anti-abortion campaigns in different parts of the country. It will as well spur the federal and state Ministries of Health to improve, promote, and intensify the provision of family planning and contraceptive services in the federation to ensure greater and correct use of contraceptive methods which will to a great extent, prevent women from unwanted pregnancies that often make them opt for abortion. If the attitude of female undergraduates and secondary school students is found positive, it will also assist the public and government to realize the threat abortion poses on the lives of the present generation as well as the existence of the future generation. This awareness will spur the government to give a more serious attention to abortion and combat it more efficiently and effectively. The findings may also be of use to the upper and lower legislative arms of government in reexamining whether or not abortion should be legalized in the country.

The result of this study will also be of great importance to the female undergraduates and secondary school students as well as their parents and guardians. It will help them to be more serious with the sexuality education of the girl child by exposing them early and regular sound sexuality education right from childhood to prevent the girl child from falling victims to abortion in the future. Furthermore, the findings of this study will assist religious groups to intensify their involvement in the fight against abortion in our society, by organizing more anti-abortion programs and family life activities. Also, it will assist social health workers in non-governmental organizations that are interested in women's welfare/wellbeing to improve on their provision of welfare services, especially in the aspect of accommodating teenage girls who get pregnant, drop out of school and are rejected by their parents.

Counselors will equally benefit so much from the result of this study as it will assist and encourage more counsellors to go into family life/ reproductive health counselling and adolescence sexuality education as a way of combating abortion.

The ministry of education will also benefit enormously from the results of this study. It will assist the ministry to review and reform school policies so that school-aged girls can return to school to complete their education in the various institutions of learning after delivery of a baby. The leadership of university and secondary education institutions, lecturers and teachers are not left out of the list of beneficiaries of the findings of this study, as the information revealed could help them improve sexuality and moral education in our tertiary and secondary institutions of learning.

\section{REFERENCES}

[1] Adeleke, N. A. (2007). Trend of induced abortion in Ilorin, Nigeria. In Anyanya, S. A., and Azikiwe, N.(Eds). Nigeria Medical Association Journal, Nnewi: Nigeria medical association. Vol. 48, No.3, July September, 2007. pp. 65.7

[2] Agbakwuru, C. and Ekechukwu, R. (2009). Sexuality education and reproductive health counseling. Owerri: Career Publishers.

[3] Alamieyeseigha DSP, Kpolovie PJ (2013). The making of the United States of America: Lessons for Nigeria. Owerri: Springfield Publishers Ltd.

[4] Alan Guttmacher Institute (2009). Sharing responsibility: women, society and abortion world-wide. New York: Alan Guttmacher Institute. Retrieved from https:/www.guttmacher.org /sites/default/files/pdfs/ pubs/sharing.pdf

[5] Anastasi, A. \& Urbina, S. (1997). Psychological Testing. Delhi: Pearson Education PVT. Ltd.

[6] Bankole, A., Oye-Adeniran, B., Adewole, I., Wulf, D., Sedgh, G. \& Husain, R. (2006). "Reducing unwanted pregnancy and induced abortion in Nigeria: causes and consequences. New York: Reproductive Health Matters.

[7] Berer, M. (2002). Making abortion safe: a matter of good health policy and practice. Reproductive Health Matters. 10(19), 31-43. Retrieved from http://www.who.int/ bulletin/ archives/78(5)580.pdf

[8] Bob, H. I. (2002), Developing the African child. Minna: Al-Mubasher Publication.

[9] Carlson, B. (2004), Human Embryology and developmental biology. $3^{\text {rd }}$ edition. Toronto: Mosby Publication.

[10] Chuck, J. (August 2007). The adoption option for children with special needs. National Council for Abortion. 
[11] Dabholker, P. A. (1994). Incorporating choice into an attitudinal framework. Journal of consumer research, June 1994, pp 100-18.

[12] Eagly, A. H. \& Chaiken, S. (1993). The Psychology of Attitude. Fort Worth, TX: Harcourt Brace Jovanovich.

[13] Federal Republic of Nigeria. (1997). Criminal code of Laws of the Federation. Lagos: Federal Republic of Nigeria. Cap 77, 3213 and 2313, 3236 and 3237.

[14] Fisher, J. (2008). Termination of pregnancy for fetal abnormality: The Perspective of a parent support organisation. UK: Reproductive Health Matters. 16 (31 supplement), 57-65. Retrieved from https:// www.jstor.org/stable/25475401

[15] Ganatra, B. (2006). Unsafe abortion in South and south -East Asia, a review of the evidence in preventing unsafe abortion and it consequences. New York: AGI

[16] Gleitman, F. A. J. \& Reisberg D. (2004). Psychology. 6th Edition. London: W. W. Norton and Company.

[17] Hawkins, D. I., Best, R. J. \& Coney, K. A. (2001). Consumer Behaviour: Building marketing strategy. New York: McGraw-Hill Companies, Inc.

[18] Henshaw S. K., Singh, S., Oye-Adeniran, B. A., Adewole, I., Iwere, N. \& Cuca, Y. P. (1998). The incidence of induced abortion in Nigeria. International family planning perspective. 1998. 24 (4), 156164. Retrieved from https://www.guttmacher.org/ journals/ipsrh/ 1998/12/ incidence-induced-abortionnigeria

[19] Hockenbury, D. H. \& Hockenbury, S. E. (2003). Psychology. (3rd edition).New York: worth publishers.

[20] Hord, E., Benson, J., Potts, J. L. \& Billings, D. L. (2006). Unsafe abortion in Africa: an overview and recommendations for action. Pp 115-150. In: I. K. Warriner \& I. H. Shah, (2006). Preventing unsafe abortion and its consequences: Priorities for research action. New York: Guttmacher Institute. Retrieved from https://www.guttmacher.org/sites/default/files/pdfs/pubs/2006/07/10/PreventingUnsafeAbortion.pdf

[21] ILO (2014). Maternity and paternity at work - Law and practice across the world. Retrieved from http://www.ilo.org/wcmsp5/groups/public/---dgreports/---dcomm/---

publ/documents/publication/wcms_242615.pdf

[22] IMF (2013). Women, work, and the economy - Macroeconomic gains from gender equity. https://www.imf.org/external/pubs/ft/sdn/2013/sdn1310.pdf

[23] Ingham, R., Lee, E., Clements, S. J. \& Stone, N. (2008). Reasons for second Trimester Abortion In England and Wales. New York: Reproductive Health Matters.

[24] Iniaghe, K. (2007). No Abortion is safe. Vanguard, P 12.

[25] Irving, D. N. (2000). Abortion: Correct application of natural law theory. The Linacre Quarterly. 67(1), 45-55. Retrieved from http://epublications.marquette.edu/cgi/viewcontent.cgi?article=2215\&context=lnq

[26] Kotler, P. (2003). Marketing management. Delhi: Pearson Education.

[27] Kpolovie PJ; Joe AI \& Okoto T (2014). Academic Achievement Prediction: Role of Interest in Learning and Attitude towards School. International Journal of Humanities, Social Sciences and Education (IJHSSE). 1(11), 73-100. https://www.arcjournals.org/pdfs/ijhsse/v1-i11/10.pdf

[28] Kpolovie, P. J, Oshodi, P. O, and Iwuchukwu, H. (2016). Continental inequities in Life Expectancy. European Journal of Biology and Medical Science Research. Vol.4, No.6, pp.30-47. http://www. eajournals.org/wp-content/uploads/Continental-Inequities-In-LifeExpectancy.pdf

[29] Kpolovie, P. J. (2010), Advanced Research Methods. Owerri: Springfield Publishers Ltd.

[30] Kpolovie, P. J. (2011). Statistical techniques for advanced research. Owerrri: Springfield Publishers Ltd.

[31] Kpolovie, P. J. (2011a). Hypothesis postulation: The what, why, how, and which? Journal of Education in Developing Areas (JEDA). Retrieved from https://www.scribd.com/doc/59132454/KPOLOVIEHypothesis-Postulation

[32] Kpolovie, P. J. (2012). Lumosity training and brain-boosting food effects on learning. International Research Journals. 2(6), 217-230. ISSN: 2026-6332. http://resjournals.com/journals/ educational-researchjournal/June\%202012/Kpolovie.pdf

[33] Kpolovie, P. J. (2013). Quality assurance in the Nigerian educational system: Matters arising. International Journal of Scientific Research in Education. 6(4), 1-85. Retrieved from www.ijsre.com/assets/vol.\%2C6(4)-kpolovie.pptx

[34] Kpolovie, P. J. (2014). Test, measurement and evaluation in education. Owerri: Springfield Publishers Ltd.

[35] Kpolovie, P. J. (2016). Excellent research methods. Indiana, USA: Partridge Publishing. http://www. kpoloviepj.com/Kpolovie, P. J. (2003). The indispensability of intelligence testing in the repositioning and revitalization of Nigerian Education. https://www.researchgate.net/publication/286562564_ Indispens 
ability_of_intelligence_testing_in_the_repositioning_and_revitalization_of_Nigerian_educationhttps://ww w.academia.edu/29930516/INDISPENSABILITY_OF_INTELLIGENCE_TESTING_IN_THE_REPOSIT IONING_AND_REV1TAL1ZATION_OF_NIGERIAN_EDUCATION

[36] Kpolovie, P. J. (2016a). Intelligence and academic achievement: A longitudinal survey. International Journal of Recent Scientific Research. 7(5), 11423-11439. Retrieved from http://www.recentscientific. com/sites/default/files/5415.pdf

[37] Kpolovie, P. J. (2017). Statistical analysis with SPSS for research. London: ECRTD Publication. http://www.eajournals.org/wp-content/uploads/Kpolovie-Statistical-Analysis-with-SPSS-for-Research.pdf

[38] Kpolovie, P. J. and Awusaku, O. K. (2016). ICT adoption attitude of lecturers. European Journal of Computer Science and Information Technology. 4(5), 9-57. http://www.eajournals.org/ wp-content/uploads/ICT-Adoption-Attitude-of-Lecturers.pdf

[39] Kpolovie, P. J. and Lale, N. E. S. (2017). Globalization and adaptation of university curriculum with LMSs in the changing world. European Journal of Computer Science and Information Technology. 5(2), 28-89.http://www.eajournals.org/wp-content/uploads/Globalization-and-Adaptation-of-UniversityCurriculum-to-LMSS-with-the-Changing-World.pdf

[40] Kpolovie, P. J. and Onoshagbegbe, E. S. (2017). Research productivity: h-index and i10-index of academics in Nigerian universities. International Journal of Quantitative and Qualitative Research Methods. 5(2), 62-123. http://www.eajournals.org/wp-content/uploads/Research-Productivity-h-Index-andI10-Index-of-Academics-in-Nigerian-Universities.pdf

[41] Kpolovie, P. J., Ewansiha, S., Esara, M. (2017). Continental comparison of Human Development Index (HDI). International Journal of Humanities Social Sciences and Education (IJHSSE). 4(1), 9-27. https://www.arcjournals.org/pdfs/ijhsse/v4-i1/2.pdf

[42] Krejcie, R. V. \& Morgan, D. W. (1970). Determining sample size for research activities. Educational Psychological Measurement. 30, 607-610. Retrieved from http://journals.sagepub.com/doi/abs/ 10.1177/001316447003000308

[43] Lindesmith, A. R., Strauss, A. L. \& Denzin, N. K. (1997). Social psychology. (5th edition) .New York: Holt, Rinewinston, Inc.

[44] Mundigo, A. I. (2006). Determinants of Unsafe Induced Abortion and Its Consequences: Priorities for Research and Action. New York: Guttmacher institute.

[45] National Population Commission Federal Republic of Nigeria (2014). Nigeria Demographic and Health Survey 2013. Abuja, Nigeria: FRN Press.

[46] National Statistical Service, Ministry of Health, and ICF. (2017). Armenia Demographic and Health Survey 2015-16. Rockville, Maryland, USA: National Statistical Service, Ministry of Health, and ICF. Retrieved from http://www.ysu.am/files/Digital_Health_Survey_Report.pdf

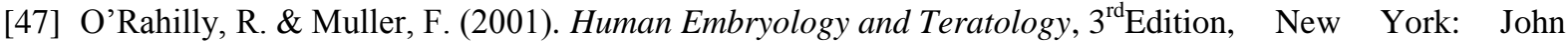
Wiley and Sons Inc.

[48] O'Rahilly, R. \& Muller, F. (2010). Developmental stages in human embryos: Revised and new measurements. Cells Tissues Organs. 192(2), 73-84. Retrieved from https://www.ncbi.nlm.nih.gov/ pubmed $/ 20185898$

[49] OECD (2017). Non-medical determinants of health. Retrieved from http://stats.oecd.org/index.aspx? DataSetCode=HEALTH_LVNG

[50] OECD (2017a). OECD statistics - Health status causes of mortality. Retrieved from http://stats.oecd.org/ Index.aspx?QueryId=30115

[51] Okoye R. C. (2006). The Untold Story of Abortion. Port Harcourt: Save A Life Foundation.

[52] Okoye Richard C. (2006). The Untold Story of Abortion. Port Harcourt: Save A Life Foundation.

[53] Olotu, E. B (2006). Guidance and counselling issues for secondary school. Ibadan: Daily Graphics Ltd.

[54] Oye-Adeniran, B. A. Henshaw, S. K.\& Singh, S. (2004). Reproductive Health Matters. 12(24), 204219.

[55] Palima, Y. line, E.\& Raya, R. (2006). Unsafe Abortion in Latin America and the Caribbean. Priority for research and action. London: Zed Books.

[56] Pazol, K., Creanga, A. A., Zane, S. B., Burley, K. D. \& Jamieson, D. J. (2012). Abortion Surveillance United States 2009. 61(SS08), 1-44. Retrieved from https://www.cdc.gov/ mmwr/preview/mmwrhtml/ ss6108a1.htm

[57] Ramachandan, L. \& Polto, P. J. (2005). Medical Abortion in Rural Tamil Nadu, South India: A Quiet Transformation. New York: Reproductive Health Matters.

[58] Ramalingam, P. (2006). Dictionary of Psychology. New Delhi. Academic (India) Publishers. 
[59] Reardon, D. (2008). Do you really want an abortion? Snowflake: Heritage House Inc.

[60] Shiers, C. V. (1999). Abnormalities of early pregnancy: in Bennett V. R. and Brown L. K. (1999) (Eds). Myles Textbook For midwives. London:Harcourt publishers limited.

[61] Shuping, M. D. \& Gacek, J. D. (2010). Post - Abortion suffering: A psychiatrist look at the effects of abortion. Retrieved from http://downloads.frc.org/EF/EF10B09.pdf

[62] Singh, S. (2006). The Incidence of Unsafe Abortion: A global review. In Warrniner I. K \& Suah I. H., (Eds). Preventing Unsafe Abortion and Its Consequences: Priorities for Research and Action. Pp $40-47$. New York: Guttmacher Institute.

[63] Wänke, M., Bohner, G., \& Jurkowitsch, A. (1997). There are many reasons to drive a BMW: Does imagined ease of argument generation influence attitudes? Journal of Consumer Research, 24, 170-177. Google ScholarCrossref.

[64] Warriner, I. K. \& Shah, I. H. (2006). Preventing unsafe abortion and its consequences: Priorities for research action. New York: Guttmacher Institute. Retrieved from https://www.guttmacher.org/ sites/default/files/pdfs/pubs/2006/07/10/PreventingUnsafeAbortion.pdf

[65] Warriner, I. k. (2006). Unsafe abortion: an overview of priority and needs. In Warriner I. K and shah, I. H., (Eds). Preventing Unsafe Abortion and its consequences: Priorities for research and Action. pp 2-14. New York: Guttmacher institute.

[66] Welch K. J. (2010). Family Life Now, Second edition. Boston, Pearson education, Inc.

[67] Winikoff, B. (2007). Second Trimester Abortion: A global overview. London: Reproductive Health Matters.

[68] Wood, W. (2000). Attitude Change: Persuasion and social influence. Annual Review of Psychology, 51, $539-570$

[69] World Health Organization (1998). Unsafe Abortion: global and regional estimates of incidence of and mortality due to abortion, with a list of available country data. Third edition. Geneva: World Health Organization.

[70] World Health Organization (2004). Unsafe abortion: Global and regional estimates of the incidence of unsafe abortion and associated mortality in 2000.Retrieved from http://apps.who.int/iris/bitstream/ 10665/42976/1/9241591803.pdf

[71] World Population Review (2017). World Population Review: Nigeria Population 2017. Retrieved from http://worldpopulationreview.com/countries/nigeria-population/

[72] World Values Survey (2015). Waves 1981-1984, 1990-194 and 2010-2014. http://www.world valuessurvey.org/WVSContents.jsp?CMSID=intinfo

[73] Wortman, C. B., Loftus, E. F. \& Marshall, M.E. (1985). Psychology. New York: Alfred A. Knopf, Inc.

[74] Yakubu, J. A. (2002). Medical Law in Nigeria, Ibadan; Demyaxs Press Ltd.

[75] Zastrow, C. \& Krist-Ashman, K. K. (2007). Understanding Human Behaviour and the social environment. ( $7^{\text {th }}$ edition). Below: Thompson books/ Cole.

[76] Zimbardo, P. G. and Leippe, M. R. (1991). The Psychology of Attitude Changeand Social Influence. New York: McGraw-Hill 


\section{AUTHORS' BIOGRAPHY}

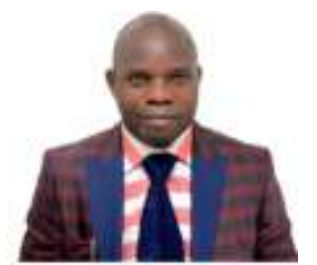

Peter James KPOLOVIE, is a professor of Educational Measurement and Evaluation at the University of Port Harcourt. He is the Director of Academic Planning, Research and Control; and a former Head of Department of Educational Psychology, Guidance and Counselling at the University. He has authored other innovative books that include, Excellent Research Methods (2016); Handbook of Research on Enhancing Teacher Education with Advanced Instructional Technologies (2015); Statistical Analysis with SPSS for Research (2017); and Educational Management in Developing Economies (2012) which are readily available online. His other great books are The Making of the United States of America: Lessons for Nigeria (2013); Test, Measurement and Evaluation in Education (2014); Educational Reforms without Evaluation Designs: Nigeria at risk (2012); Statistical Techniques for Advanced Research (2011); and Advanced Research Methods (2010). He has published over 160 journal articles that are internationally accessible online. He may be reached via E-mail, kpolovie@gmail.com.

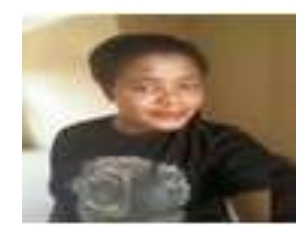

Amarachi OGUWIKE, is a highly industrious research student in the Department of Educational Psychology at the University of Port Harcourt. She is passionate in specializing in behavioural psychology.

Citation: Kpolovie, P. J. \& Oguwike. A. "Female Students' Attitude towards Abortion." International Journal of Humanities Social Sciences and Education (IJHSSE), vol 4, no. 11, 2017, pp. 98-120. doi:http://dx.doi.org/ 10.20431/2349-0381.0411012.

Copyright: () 2017 Authors. This is an open-access article distributed under the terms of the Creative Commons Attribution License, which permits unrestricted use, distribution, and reproduction in any medium, provided the original author and source are credited. 